IZA DP No. 4512

Reversals in the Patterns of Women's Labor Supply in the U.S., 1976-2009

Diane J. Macunovich

October 2009 


\title{
Reversals in the Patterns of Women's Labor Supply in the U.S., 1976-2009
}

\author{
Diane J. Macunovich \\ University of Redlands \\ and IZA
}

\section{Discussion Paper No. 4512 \\ October 2009}

\author{
IZA \\ P.O. Box 7240 \\ 53072 Bonn \\ Germany \\ Phone: +49-228-3894-0 \\ Fax: +49-228-3894-180 \\ E-mail: iza@iza.org
}

\begin{abstract}
Any opinions expressed here are those of the author(s) and not those of IZA. Research published in this series may include views on policy, but the institute itself takes no institutional policy positions.

The Institute for the Study of Labor (IZA) in Bonn is a local and virtual international research center and a place of communication between science, politics and business. IZA is an independent nonprofit organization supported by Deutsche Post Foundation. The center is associated with the University of Bonn and offers a stimulating research environment through its international network, workshops and conferences, data service, project support, research visits and doctoral program. IZA engages in (i) original and internationally competitive research in all fields of labor economics, (ii) development of policy concepts, and (iii) dissemination of research results and concepts to the interested public.
\end{abstract}

IZA Discussion Papers often represent preliminary work and are circulated to encourage discussion. Citation of such a paper should account for its provisional character. A revised version may be available directly from the author. 


\section{ABSTRACT \\ Reversals in the Patterns of Women's Labor Supply in the U.S., 1976-2009}

Despite strong increases in women's labor force participation - especially among married women with children - in the 1980s, and somewhat less strong increases in the 1990s, the first decade of the twenty-first century has seen declines across the board. These have been especially marked among single women, women with no children, and women with more than 16 years of education. Single women with no children have experienced declines of 7.2, 6.2 and 3.6 percentage points since the late 1980s, among women with less than 16, 16, and more than 16 years of education, respectively. Own-wage elasticities have increased since 2000 , after decreasing in the previous 20 years, and the absolute value of cross-wage elasticities has also increased, after declining for at least 20 years. Despite this, the absolute value of elasticities with respect to the presence of children has for the most part continued to decline. Measured factors cannot explain the marked declines in hours worked that have been observed, suggesting that while the labor supply function was hypothesized to have shifted to the right in the 1980s and 1990s, it has shifted back to the left since the late 1990s. And the characteristics of single and childless women dropping out of the labor force after 1999 have changed: they on average had worked more hours, earned more per hour, enjoyed less other income, and had fewer children, than those who had dropped out prior to 1999.

JEL Classification: J21

Keywords: women's labor force participation, women's labor supply, opt-out revolution, women's own-wage elasticities, effect of children on women's labor force participation

Corresponding author:

Diane J. Macunovich

Department of Economics

University of Redlands

Redlands, CA 92346

USA

E-mail: diane_macunovich@redlands.edu 
Married women's labor force participation - which has been the focus of most analyses in the past 15 years - increased dramatically in the 1970s and 1980s, as reported by DiNatale and Boraas (2002), and Juhn and Potter (2006), among many others. But the labor force participation of married women especially those with children - increased only marginally in the 1990s, and began to decline toward the end of the 1990s. For married women with children for example, the rate increased from $39.7 \%$ to $66.3 \%$ between 1970 and 1990, but then to only $70.6 \%$ in 2000 and to $69.3 \%$ in 2007 . For married mothers with infants, the rate peaked in 1997 at 59.2\% and declined to 53.5\% in 2005 (Cohaney and Sok, 2007).

The declines in the last decade have been chronicled anecdotally in the popular press, where reporters tend to refer to it as the "opt-out revolution" (Belkin, 2003). Wallis (2004) noted that this often appears to occur among professional and managerial women, "where higher incomes permit more choices". Similarly, Bradbury and Katz (2005) found that declines in labor force participation were highest among highly educated women and married women with young children and high-earning husbands. This effect is also indicated by Hirshman (2005), whose own survey of women whose marriages were reported in the New York Times showed that "Half the wealthiest, most-privileged, best-educated females in the country stay home with their babies rather than work in the market economy". Similarly, Shipman and Kay (2009) suggest that a revolution is occurring among professional women in which employers accede to more flexible work schedules for working mothers.

This would seem to be consistent with trends in other observed characteristics. Thornton and YoungDeMarco (2001), using the results of four large social surveys covering the years 1976-1998, found that "as compared to the 1970s, young Americans in the 1990s were more committed to the importance of a good marriage and family life". They found that agreement with the statement that there are "more advantages to being single than married" declined from 23\% among women and 34\% among men in 1980 , to $11 \%$ \& $12 \%$ in 1993 . They concluded that "although marriage became more optional and was perceived as more restrictive between 1957 and 1976, these trends do not seem to have continued into the 
1980s and 1990s". And Hoffman (2009), looking at female labor force participation between 1984 and 2004, found that while fertility among 20-24 year olds fell by 3.3\% between 1993 and 2004, fertility was up $20 \%$ for women aged $30-34$ and up $44 \%$ for women aged $35-39$. He found that while single women with children were more likely to work in 2004 than in 1984, married women with children were less likely to do so. DiNatale (2001) found that workers in 1999 were more likely to prefer alternative work arrangements (contract, on-call or temporary work), than workers in the mid 1990s.

But more recent work objects to the notion that this opting-out is a voluntary phenomenon (Williams, 2007).The work documents many cases in which women have been "pushed out by workplace inflexibility, failures of public policy [the lack of adequate chidcare], and workplace bias", referring even to some of the women mentioned in Belkins' earlier "opting-out" article. She maintains that the phenomenon arises from "systemic discrimination", rather than mothers' own choices. Wallis states that "a reluctant revolt is under way. Today's women execs are less willing to play the juggler's game." But at the same time Williams states that "highly educated women are more - not less - likely to remain in the labor force than other women".

Boushey (2005) maintains that the notable declines in the labor force participation of mothers with children is due largely to cyclical economic conditions, with women becoming unemployed in the 2001 recession and choosing to become "discouraged workers" staying at home with children, rather than search for elusive employment. This hypothesis is hard to justify, however, in light of the fact that women's labor force participation rates began to decline before 2000. For women 25-34 the decline began in 1998/9, while for women aged 35-44 it began in 1997. For women with children under 3 it began in 1998. (Mosisa and Hipple, 2006). The claim also contradicts evidence from survey data reported by Story (2005), who found that young women in elite colleges "say they have already decided that they will put aside their careers in favor of raising children". Similarly, Vere (2007), using a cohort rather than time series analysis, found that "the women of Generation $\mathrm{X}$ are not only having more 
children than women from the baby boom generation but are also supplying fewer hours to the labor market". He found that this appears not to be simply a timing effect, since these women report a $34 \%$ increase in the desired number of children relative to women born in 1956-1957. He states that "if the trends reflect differences across cohorts, then the recent decline in female labor force participation in the United States is only the tip of the iceberg, and female labor force participation will fall even further as women of the baby boom generation - now in their 40s and 50s - retire from the labor force".

And Williams (2007) emphasized that the trend - whatever its causes - has been misrepresented in terms of the experience of these women when they attempt to return to the labor force, or to resume full-time work, if they have simply moved away from demanding jobs requiring more than 40 hours per week. "Women who work part time earn 21\% less per hour than full timers. . .On average people who work 44 hours per week in the United States earn more than twice what those working 34 hours per week earn." And she cited a study by the Wharton Center for Leadership and Change which found that "while 70\% of those surveyed reported feeling positive about their decisions to leave the labor force, $50 \%$ felt 'frustrated' when they tried to return to work, and 18\% became 'depressed'". In addition, Golden (2001) reported that in order to achieve flexible work schedules, women must often accept either an increase in working hours, working an evening shift, or switching to part-time status. This can often entail considerable hardship.

Thus the trend is an important one to study using more comprehensive data. What are its long-term implications? The Board of Trustees of OASDI (2009) has projected that the overall women's labor force participation rate will increase from a 2007 level of 59.3\% to a level of $60.4 \%$ by 2083, in their intermediate projection. This projected increase implies a continued increase in the participation rate of married women, so it's important to examine recent trends to try to determine underlying causation. Do the most recent declines signify the beginning of a trend - or are they simply, as some have speculated, an artifact of the business cycle? 
There have been a number of studies examining econometrically the rise of women's labor force participation prior to 2003, with no focus on possible changes occurring after the mid 1990s. Blau and Kahn (2007) used CPS data to focus primarily on own and cross-wage elasticities among married women with spouse present, aged 25-54, finding a sharp decline from 1979/81 to 1989/91 that attenuated in moving to 1999/2001. They also found a pronounced rightward shift of the labor supply function in the 1980s, but little change in the 1990s. They indicated that little of the declining effects they found for the 1990s could be traced to a change in wages, since real wages actually increased in that decade.

Heim (2007) also used the CPS and focused on elasticities among married women aged 25-55 between 1979-2003, finding declines in elasticities similar to those found by Blau and Kahn. But like Blau and Kahn, Heim did not specifically note differences that occurred in the late 1990s. His graphs of annually estimated income elasticities with respect to participation, however, indicate a slight increase in the absolute value of the elasticity that began in the late 1990s, suggesting that women in this period became more responsive to changes in their non-labor income (typically the husband's income, which Heim included in his "other income" category). This would suggest that declines in participation in this period may have been driven at least in part by increases in husbands' wages.

Heim also attempted to estimate the proportion of the measured changes in elasticities that was due to simple changes in the demographic characteristics of the women in the samples. That is, changes in the age composition of the sample as baby boomers aged, or changes in education levels, or changes in the presence and number of children that might affect the magnitude of changes in elasticities that were observed. However, he found that in fact the decline in elasticities would have been even greater had demographic characteristics not shifted. Thus, the shifts must be due to unobserved rather than compositional factors. 
Interestingly, Heim, Bishop and Mihaly (2009) conducted a similar type of analysis for single women, and found similar declines in elasticities between 1979 and 2003 - and here again the income elasticity of participation showed a slight increase in absolute value in the late 1990s. In addition, the hours income elasticity also showed a slight increase in that period.

Three studies, Hotchkiss (2006), Boushey (2005), and Hoffman (2009) focus specifically on the change in labor force participation that has occurred since the mid 1990s. Hotchkiss used CPS data for all women aged 25-54 between 1975 and 2005, and found that in the 2000-2005 period there was a declining positive response of labor force participation to education, and a declining negative response to unemployment, as well. She found that even if the 2005 unemployment rate had remained at its pre-recession level, women's labor force participation "would still be significantly lower than it was in 2000". Her findings contradict those of Boushey, who found that "the business cycle penalty is significantly greater in 2004 than in 2000 for all educational groups except for women with advanced degrees and either younger or older children and women with less than a high school degree and any children." Hotchkiss found that the greatest contributor to the observed decline between 2000 and 2005 is "unobservables", which by definition cannot be identified or forecast.

Boushey (2005), using logit on the CPS Outgoing Rotation Group for 1984-2004 for all women aged 2544, focused on the possible effect of the presence of children on women's participation during this period, and found, if anything a declining "child penalty". Further analysis led Boushey to hypothesize that the decline in labor force participation rates during this period was a result of the 2001 recession - but this identification comes from the use of year dummies, rather than actual unemployment rates. And as pointed out earlier, this does not explain why the decline began, for nearly all groups, before 2001.

Boushey's finding is supported to some extent by Hoffman (2009), using the same data and the same model specification as Boushey. He also found a decreasing negative effect of children, on mothers' labor 
force participation using that model specification. And in all specifications of his model he found an increasingly negative effect of the year dummies that proxied for unemployment.

However, when marriage-year interaction terms were added to Boushey's specification Hoffman found that while the negative effect of marriage declined from 1984 through 1993, it then increased from 1993 to 2000 and again from 2000 to 2004. By 2004 he found that the negative effect of marriage was nearly as large as it had been in 1984, even after controlling for year effects. Neither Boushey's nor Hoffman's analyses included any controls for income and wages.

In addition, Hoffman added marriage-child-year interaction terms to Boushey's regressions, in both OLS and logit formulations, in order to differentiate the effect of children on married women, separate from their effect on single women, in each year. He found that in 1984 the negative effect of children on married women was 15.5 percentage points lower than on single women. He then found a decreasingly negative effect of children on single women from 1984 through 2004, to the point where children had virtually no effect on single women's participation by 2004.

However, Hoffman found that while the negative effect of children on married women decreased from 1984 through 1993, it increased in absolute value by nine percentage points between 1993 and 2000 in the OLS formulation, and then remained at basically the same level through 2004, to the point where the 2004 level was larger than that in 1984. The logit estimates follow the same pattern, and show that the net change in relative position, moving from 1984 and 1993 to the 2000s, is almost 20 percentage points. As Hoffman points out, these results are similar to the pattern found by Cohaney and Sok (2007) for mothers with infants.

While the results reported above for Hoffman describe the effect of all children under 18, Hoffman also considered separately the effect of children 0-5 and children 0-2. He found that the results for 2000 and 
2004 were even more pronounced for this group, with married mothers with children aged 0-2 a full 12.2 percentage points less likely to be in the labor force, than their counterparts in 1989. However, as mentioned earlier, Hoffman's analysis excluded controls for income and wages.

The question that arises, then, is what has happened since 2004? We now have data from the CPS through 2009, and in fact data after 2004, using Hoffman's methodology, suggest a leveling off in the rates, or even a slight increase. Hoffman's results indicated that more change occurred from 1993-2000, than from 2000-2004. Were the effects measured in these studies simply a one-off occurrence, or have they persisted - and did these analyses provide spurious results given the lack of controls for income and wages?

\section{An Examination of Recent Trends in Women's Participation Rates}

Given the varied pictures presented in the literature to date, it is worth examining actual trends in female labor force participation, by marital status, education level, and presence of children. This is accomplished here using detailed breakdowns of data provided in the March Current Population Survey (CPS), for women aged 25-54 in the years 1976-2009.

Figure 1 looks first at overall labor force participation by marital status ${ }^{1}$ and level of education, for women aged 25-54. The graphs down the left side present the data for married women, who have been the focus of virtually all of the recent literature. There one can see the declines in participation of women with children beginning as early as the mid-1990s, that are strongest for women with $16+$ years of education. These declines would be the ones that triggered the various articles in the popular press, about professional women moving to the "Mommy track". For those with at least 16 years of education, the trend has reversed to some extent in the period after 2000 - but for those with less than 16 years of

\footnotetext{
1 "Married" is defined here, as in Blau and Kahn (2007), as married with spouse present. "Single" includes married with spouse absent, and divorced, separated, widowed and never-married women.
} 
education, with children under 6 , the decline has proceeded nearly unabated. There has even been some decline beginning in the early 1990s among married women with no children under 18, with 16 years of education.

That decline among women with no children under 18 has been even more pronounced for single women, shown in the panels to the right in Figure 1. Single women with no children have experienced declines of 7.2, 6.2 and 3.6 percentage points since the late 1980s, for women with less than 16, 16 and 16+ years of education, respectively. Single women with at least 16 years of education have also shown declines among those with children under 6 - although there has been a rebound among women with $16+$ years of education. Women with children, with less than 16 years of education, exhibited marked increases in participation after the mid 1990s, as a result of welfare reform, but their rates have declined by about 3.5 percentage points since the turn of the century. On the whole the picture has been one of decline for all single women, extending in several case back to the late 1980s or early 1990s.

However, much more significant trends underlie the patterns in Figure 1. Figures 2 and 3 examine these trends more closely, looking at single and married women by education level by five year age group. Figure 2 looks at women with children under 6, while Figure 3 looks at women without any children under 18.

The significant movement in Figure 2 in recent years has been among women aged 25-29 with children under 6 - where rates have declined for single college graduates ${ }^{2}$ (over 9 percentage points), married college graduates (nearly 7 percentage points), married less than college (over 8 percentage points) and single less than college (nearly 3 percentage points) - and among single college graduates aged 40-44 (declined over 12 percentage points). Rates for women with no college degree aged 30-34 have also

\footnotetext{
${ }^{2}$ For ease of exposition, the phrase "college graduate" refers to all women with 16 or more years of education, while the phrase "less than college" refers to those with less than 16 years of education.
} 
declined marginally. The trend among single college graduates aged 40-44 corresponds with the many recent articles about older women with young children withdrawing from the labor force - although those articles tended to focus almost exclusively on married women. And those articles appear to have missed the trend among 25-29 year olds: this is a significant one which may signal a cohort shift in behavior.

Perhaps the most surprising results are presented in Figure 3, however, which looks at women without any children under 18. Here we see declines—most extending back to the early 1990s or even late 1980s - among all education, marital, and age groups except for college graduates aged 35-39. The trends in these graphs seem to contradict the hypothesis that children are the reason for women's labor force withdrawal.

Accompanying these marked changes in labor force participation, there has been a notable increase in the numbers of children since 2000, for almost every group. The overall figures can be seen in Tables A-2 and A-3, which show an increase of $7.7 \%$ in the number of children under 6 for married women, and an increase of $15.5 \%$ in the same measure among single women. In some subgroups, the increase was much more marked. This was particularly so among women with more than 16 years of education: married women's number of children under 6 increased by 24.9\% between 2000 and 2008, while single women's number of children aged 6-17 increased by $29.6 \%$ in the same period. For single women with 16 years of education, the number of children under 6 has increased by 27.9\% since 2000.

\section{Data and Methodology}

The objective in this study was to examine trends econometrically in an update of the Blau and Kahn (2007) study, which estimated hours-wage elasticities for married women and found a declining trend between 1980 and 2000. As mentioned earlier, their analysis covered the years up through 2000/2001. They also found evidence of a sharp rightward shift of the labor supply function for married women during the 1980s. They modeled annual hours worked in three, three-year groupings - 1979-1981, 1989- 
1991, and 1999-2001 - using data from the March Current Population Survey (CPS) for married women aged 25-54 with spouse present, together with their spouses.

Thus the analysis presented here also drew on CPS data for women aged 25-54 (including the husbands of those married with spouse present). The Blau and Kahn three year groupings were used, updated by including the 2007-2009 period. In addition, this analysis included the 1984-1986 period in order to examine trends throughout the 1980s, when female labor force participation was increasing at the fastest rate, before the declines seen in Figures 1-3.

The analyses presented here looked not just at married women with spouse present, but also at single women - a group that has been defined here as including married women with spouse absent, and divorced, separated, widowed and never-married women. This latter group was included because of the significant trends observed for them in Figures 1-3. Both groups (including husbands for married women) excluded those in the military, the retired, and those with allocated hours or weeks worked. March supplement weights were used throughout the analysis, with weights divided by the sum of weights in each year in order to ensure that each year in a three-year grouping received equal weight. Summary statistics for the data used are presented in the Data Appendix.

The model estimated was

$$
H=\beta_{0}+\beta_{1} \ln W_{w}+\beta_{2} \ln W_{h}+\beta_{3} I+\mathrm{B}^{\prime} X+u
$$

Where $H$ is annual hours worked (including those with zeroes); $W_{w}$ is the woman's own (instrumented) wage; $W_{h}$ is the husband's (instrumented) wage, which is excluded from the equation for single women; $I$ is other income, which comprises interest, dividends and rent; and $X$ is a vector of control variables. The control variables include age, age squared, four education dummies, and three race dummies - for wife and husband in the married women's equation, and for the woman only in the single women's 
equation - number of children under 6, number of children aged 6-17, two year dummies, eight region dummies and two indicators of MSA status.

The methodology comprised three steps. In the first, hourly wages were calculated - in 2008 dollars using the Consumer Price Index - as total annual wages and salary divided by annual hours worked, with the latter calculated as weeks worked times the usual number of hours worked per week in the previous year. The annual wages and salary were first multiplied by a factor if 1.45 if topcoded, as in Blau and Kahn. The hourly wage was imputed for those with no reported wage, the self-employed, and those whose calculated wage fell outside the range \$2.50 - \$250 in 2008 dollars (again following Blau and Kahn). The imputation process was based on separate logwage regressions for those with less than 20 weeks worked and those with 20 or more weeks worked, separately for men, married women, and single women. That is, it was assumed, as in Blau and Kahn, that wages should be imputed based on the reported wage of those in groups with similar numbers of weeks worked. The regressions included - as in Blau and Kahn - age and age squared, together with two year dummies, four education dummies, three race dummies, eight region dummies, and indicators for central city and other MSA.

In the second step, treating own and spouse wages as endogenous, wages were instrumented by regressing logwage on age and age squared, four education dummies, three race dummies, eight region dummies and two indicators for MSA status. In addition, following on Blau and Kahn, a series of dummy variables representing wage deciles was included, which served as excluded instruments in the final hours equations. As indicated in Blau and Kahn, use of the deciles "corrects to some degree for measurement error in the wage" (p. 406).

The third step involved estimating the equation in (1), with results presented, for married and single women, in Table 1. This was treated as a weighted IV linear model. However, two alternative methods were tested, for sensitivity. In the first, as in Blau and Kahn, a median regression was estimated, to allow 
for the fact that with higher levels of labor force participation many women might be constrained to a standard work week. A regression at the median removes this constraint. The results of that median regression are presented, for married women, in Table 2. The second alternative method was based on Heim (2007), who used the Heckman method, estimating an inverse Mills ratio to be included in a logwage regression, to produce a predicted logwage to be included along with the inverse Mills ratio in a regression for hours worked ${ }^{3}$. The results of that procedure - which correspond very closely to the ones presented in Table 1 - are available from the author on request.

\section{$\underline{\text { Results }}$}

The results in Table 1 correspond with those in Blau and Kahn, in the decline in own-wage elasticity moving from the 1980 period (.531) through the 1990 period (.522), to the 2000 period (.253) - although the overall magnitude of the elasticities is less than that of the ones estimated by Blau and Kahn (.766, .584 and .357).

However, as suggested in Juhn and Murphy (1997), the own wage elasticity estimated here actually increased during the first half of the 1980s, before beginning its decline (from .531 in the 1980 period, to .591 in the 1985 period, before declining to .522 in 1990). More notable in Table 1, however, is the fact that the own wage elasticity appears to have risen again between the 2000 period and the 2008 period (from .253 to .292). A similar pattern is demonstrated in the bottom half of Table 1, for single women, where the own wage elasticity first increases between 1980 and 1985, declines to .115 in 2000, but then rises to .202 in the 2008 period.

\footnotetext{
${ }^{3}$ The Heim model for hours supplied included age, years of education, the unemployment rate (by state, age, and education group, calculated from the CPS), non-wage income (including husband's earnings for married women), two year dummies, three race dummies, three region dummies and two indicators of MSA status (and the IMR). The model for the logwage included the cubics of age and years of education, two year dummies, three race dummies, three region dummies and two indicators of MSA status (and the IMR). The model for estimating the IMR included the cubics of age and education, two year dummies, the unemployment rate , the number of children under 18 and an indicator of the presence of children under 6 , three race dummies, metropolitan size, three region dummies and two indicators of MSA status.
} 
Similarly, the absolute value of the cross-wage elasticity presented in Table 1 for married women declined from 1980 to 2000 (from -.298 to -.131), as in Blau and Kahn, but it, too, increased in absolute value between 2000 and 2008 (from -.131 to -.154).

The patterns displayed in Table 1 are mirrored in those presented in Table 2, based on a median regression. There, the own-wage elasticity initially rises from .736 to .760, then declines to .271 in the 2000 period - but rises again to .281 in 2008. And, as in Table 1, the cross-wage elasticity falls from 1980 through 2000, but then rises between 2000 and the 2008 period.

In order to explore this pattern further, separate regressions were estimated for various sub-groups of married and single women, and the resulting elasticities are presented in Table 3. Except for single women college graduates, we see the same increase in own-wage elasticities between 1980 and 1985 followed by a decline between 1990 and 2000 in all groups - and except for married women with less than a college degree, and single women under 35, we see the increase in own-wage elasticity between 2000 and 2008 that was demonstrated in Tables 1 and 2. For single women with more than 16 years of education, the own-wage elasticity actual turned negative during the 1990s - probably a result of the dotcom boom during the late 1990s, causing women to enjoy the income effect of their own wage. This effect is consistent with Goldin's (1990) expectation that as women become more career-oriented, their own-wage elasticities will approach those of males.

And for cross-wage elasticities, the pattern in Table 3 echoes that in Tables 1 and 2 for all groups, except those with children under 6 - where the elasticity failed to increase between 2000 and 2008. But in general, the pattern has been one of decline in the cross-wage elasticity from 1980 through 2000, with a rebound thereafter. 
Tables 4 and 5 present estimated elasticities in term of the responsiveness of mothers' hours worked to number of children in two age groups: under 6, and 6-17. In nearly all cases we see the responsiveness declining throughout the 1980-2008/9 period: children having less and less influence on their mothers' hours worked. We do see a very marginal increase between 2000 and 2008, in the responsiveness to the number of children under 6 , on the part of married college graduates and married women with children under 6. Similarly, there is a very marginal increase between 2000 and 2008 in the elasticity of single college graduates and single women under 35, to the number of children under 6.

\section{Interpretation of Results}

In order to try to determine what factors lie behind the marked changes in labor force participation seen in Figures 1-3, and the changes in elasticities seen in Tables 3-5, it is helpful to look at predicted values of labor supply based on the estimated equations underlying Tables 3-5. These predicted values can be broken down into component parts, and total predicted values can be compared with actual observed changes in labor supply. The results of such a procedure are presented in Tables 6 and $7^{4}$. Table 6 breaks down predictions for the 1980s, when labor supply increased most dramatically in all groups, while Table 7 does the same for the 2000-2009 period, when so many reversals appear to have occurred.

Each table looks at married and single women separately. Looking first at Table 6, for the 1980s, lines 12 and 22 indicate the actual change in hours worked that occurred for each group. There it can be seen that significant increases occurred in all groups, but by far the most dramatic increases occurred for married women, where the increase over all married women was 276.42 hours, while for single women the comparable figure was 118.2 hours. For both married and single women, the largest increases occurred among those with 16 years of education, and those over 34 years of age. But close behind were married

\footnotetext{
${ }^{4}$ Table 6 is based on the regression equation reported in Table 1 for the period 1989-1991. But results based on the equations for other years produce very similar results. Similarly, Table 7 is based on the regression equation for 2007-2009, although similar results were obtained using equations from the other years. Results available on request.
} 
women with children under 6 - the group that has been most often noted in the literature, for its sharp increase in participation in the 1980s.

The most significant driving force behind these increases, for married women, appears to have been their own wage (line 1), where the average increase attributable to the wage was 59.77 hours. This is followed by increases in educational levels, which contributed another 19.49 hours (line 6). Husbands' wages contributed, as well, since their average wage declined during this period, leading women to supply more hours. For single women, the most significant contribution to increased hours was made by improving educational levels, which brought about an average increase of 36.42 hours (line 18). For both married and single women, children made a positive contribution to hours worked (lines 8 and 19), since fertility declined overall during this period.

However over all, the predicted increases fall far short of the actual observed increases in hours worked (lines 13 and 23). This same phenomenon was observed by Blau and Kahn for this period: they found that measured factors accounted for at most $38 \%$ of observed increases, suggesting a marked shift to the right of the labor supply function during this period. In this analysis, the result is similar, with measured factors accounting for only $38.7 \%$ of the increase for married women, although the performance is better for single women, with measured factors accounting for $65.2 \%$ of the observed change. Thus the attitudinal shift occurred most significantly among married women, probably because of the gradual acceptance of labor force participation among women with young children.

The poorest performance, in terms of explaining increases in hours worked - indicating the greatest shift in the labor supply curve - was for women under 35, where measured factors accounted for only $22.5 \%$ of observed changes for married women, and $14.4 \%$ for single women. The best performance was for women over 34: $49.7 \%$ for married women, and $79.2 \%$ for single women. 
Table 7 performs a similar analysis for the 2000-2009 period, based on the estimated equation for 20072009 that was presented in Table 1. But whereas the unexplained portions of hours increase were all positive in Table 6 (lines 14 and 24) - indicating a rightward shift of the labor supply function - with one exception they are all negative in Table 7 (again, lines 14 and 24). This, together with the estimated turnaround in elasticities in the 2000-2009 period, suggests that the labor supply curve may have shifted back to the left during this period. This appears to be the case especially for single women, where the observed declines in hours worked were the greatest (line22). The overall change in hours for single women was a drop of 101.48, as compared to a decline of only 13.46 hours for married women. But measured factors would have predicted a rise of 6.44 hours for single women, instead of the observed large decline.

The one exception to the rule in Table 7, is married women with more than 16 years of education: there, measured factors predicted an even larger decline in hours worked, than actually occurred. They also had the largest decline attributable to the presence of children: 30.32 hours lost (line 8), which is very close to the observed overall drop of 28.66 hours supplied (line 12). This is the only case in Table 7 where children might be thought responsible for women's reduction in hours worked in the labor market. For all other groups, the contribution made by children - despite the significant rise in fertility - was fairly small (lines 8 and 19). Married women with 16+ years of education were joined by single highly educated women who, as noted earlier, exhibited a negative own wage elasticity in the 1999-2001 period, and essentially bought back time due to the income effect of their wages.

For women in the 2000-2008 period, movements in their own wage were much less significant, in affecting hours supplied (lines 1 and 15). In fact, for single women in nearly every group, despite positive own wage elasticities, the wage was responsible for a drop in labor supply, rather than an increase (line 15). This is due to the fact that their imputed, instrumented, average wages decreased during this period, as shown in Table 8. 


\begin{tabular}{|l|c|}
\hline \multicolumn{2}{|c|}{$\begin{array}{c}\text { Table 8: Decrease in imputed and } \\
\text { instrumented wages for single } \\
\text { women } 2000-2008\end{array}$} \\
\hline All women & $-1.0 \%$ \\
\hline With >16 years education & $-1.8 \%$ \\
\hline With 16 years education & $-1.1 \%$ \\
\hline With <16 years education & $-2.6 \%$ \\
\hline Over 34 years old & $-1.1 \%$ \\
\hline With no children $<18$ & $-1.6 \%$ \\
\hline With children $<6$ & $-1.1 \%$ \\
\hline
\end{tabular}

For single women without children under 18 part of this decrease in the average estimated wage was probably due to a decrease in the proportion of women with more than 16 years of education: their share fell by $13 \%$ during this period, (although this was nearly matched by a decrease of $11 \%$ in the share of women with less 12 years of education during the same period). This decline in the share of women with more than 16 years of education was not due to a decline in the overall share of more highly educated women: their share among all married women aged $25-54$ rose by $41 \%$, while the share among single women overall rose by $12 \%$ (Tables A-2 and A-3). Similarly their share among single women with children rose by $29 \%$. Thus, women with the highest levels of education were marrying and having children in fairly high proportions during the 2000-2008 period. This would be another feature of the period that attracted so many articles in the popular press.

The movement in their instrumented wages follows the overall pattern that occurred during this period, shown in Figure 4. Figure 4 presents actual observed wages of women reporting positive hours worked and positive earnings, in the period from 1976-2009 (for earnings in 1975-2008). This is as opposed to the imputed and instrumented wages used in the estimating regressions. Figure 4 shows a strong period of increase in women's average wages, in nearly all age groups, between 1980 and the early 2000s. For women 25-29 this increase did not begin until the mid 1990s, explaining the smaller effect of own wage on hours supplied to the labor market during the 1980s, for these younger women. However, after the early 2000s women's wages decreased across the board, for all age groups. This was especially the case 
for women aged 25-29 - a possible reason, taken together with their increased responsiveness to their own wage, for their significant reduction in labor force participation, shown in Figure 3.

\section{Characteristics of Women Who Drop Out of the Labor Force}

How do women who drop out of the labor force differ from those who remain - and have these characteristics changed in the most recent decade? Table 9 considers this question, looking at the two groups who have for the most part dropped out in the greatest numbers: single women, and those without any children under 18 . The table presents the characteristics of such women, relative to those of women who remained in the labor force, by education level. Thus, for example, in the upper left hand corner, prior to 1999 women with less than 16 years of education who dropped out of the labor force had worked only $48.7 \%$ as many hours as those who did not drop out. This is a pattern that is common across years and levels of education, for both single women and childless women, but also common to the pattern is the fact that after 1999 the dropouts had worked slightly more relative to those who remained.

Similarly, those who dropped out had on average earned less than $85 \%$ per hour of those who remained prior to 1999 - but this percentage rose in all cases after 1999. In the 2000 period in all but one case they had earned more than those who had not dropped out. However prior to 1999, those with 16+ years of education had enjoyed more than 50\% more other income (interest, dividends and rent) than those who remained - but in all cases this advantage dropped significantly after 1999.

And finally, except for those with the highest levels of education, those who dropped out had, on average, more children than those who did not drop out. But here again there was a shift after 1999: this ratio had dropped. The only instance in which the ratio rose was for women with more than 16 years of education in the 2000 period: they had 23\% more children in that period, after having had 8\% fewer prior to 1999. This again is consistent with the "opting out" stories reported in the popular press. 
Thus, as reflected in the shifts in elasticities reported in earlier tables, there were significant shifts in the characteristics of those who dropped out after 1999: they on average had worked more hours, earned more per hour, enjoyed less other income, and had fewer children.

\section{$\underline{\text { Conclusions }}$}

Much of the received wisdom regarding women's labor force participation has been turned on its head in the last decade. Already widely noted has been the decline in labor force participation among highly educated married women with children under 6, in many cases beginning in the mid-1990s. But what seems to have passed under the radar has been the significant change that has occurred among women without children under 18, and especially among single women, where declines have been occurring since the early 1990s and even the late 1980s. Also notable have been the declines that have occurred in the 25-29 age group, where declines among all groups of women began as early as the late 1980s and have continued unabated, except among single women with no children. In addition, women with more than 16 years of education have been marrying in large numbers, and both single and married among the highly educated have been having children, with numbers of children increasing by more than 25\% since 2000 .

In some case these trends have abated somewhat since about 2005, but for nearly all women without children under 18, and for women with children, with less than 16 years of education, the declines have continued through 2009.

The analysis in this paper has attempted to analyze these trends econometrically, and has found several significant trends. Own wage elasticities, which had been declining since the 1980s, have increased since 2000 for both married and single women; and cross-wage elasticities for married women, which had been declining in absolute magnitude since 1980, have increased in absolute value since 2000. 
These changes have occurred at the same time that the negative elasticities with respect to number of children for nearly all women have declined continuously in absolute value since 1980. The only exception to this rule has been among married women with more than 16 years of education, and married women with children under 6, where elasticities have increased marginally in absolute value since 2000. Among single women, elasticities with respect to children have declined continuously since 1980 for all except for those with 16 years of education, and those under 35 - with respect to children under 6 - and for those with more than 16 years of education with respect to children aged 6-17, where elasticities have increased very marginally in absolute value since 2000.

But for the most part the observed changes in elasticities cannot explain the marked changes in number of hours supplied to the labor market since 2000. The overall drop in hours supplied for single women was 101.48, but measured factors would have predicted a rise of 6.44 hours. For married women the actual drop was only 13.46 hours, but here again measured factors would have predicted a rise of 8.79 hours. These differences suggest that, whereas the labor supply curve appeared to have shifted markedly to the right in the 1980s, and more marginally to the right in the 1990s, there was a leftward shift between 2000 and 2009, which was most marked for single women.

The only exception to this rule was for married women with more than 16 years of education, where measured factors would have predicted an even larger drop in hours supplied, than actually occurred. This was largely due to their response to the presence of children: the only case where the decline in women's labor force participation might be attributed to the presence of children.

Thus this analysis, unfortunately, leaves largely unexplained the sometimes dramatic shifts that have occurred in women's labor market behavior since the 1990s - especially among single women. Perhaps, like the attitudinal shift that occurred in the 1970s and 1980s, making it more acceptable for a mother with children to enter the labor force, we are now seeing an attitudinal shift that accepts women's ability 
to choose between home and labor market. Beyond the scope of this study, but calling for further analysis, is an examination of the sources of income, and the living arrangements, of those single women and childless women who have been choosing to withdraw from the labor force since the turn of the century. 


\section{Bibliography}

Belkin, Lisa (2003). "The opt-out revolution", New York Times Magazine, October 26, 2003.

Black, Sandra and Chinhui Juhn (2000). "The rise of female professionals: are women responding to skill demand?", American Economic Review, 90(2):450-455.

Blau, Francine and L.M.Kahn (2007). "Changes in labor supply behavior of married women 1980-2000", Journal of Labor Economics, 25(31):393-438.

Blundell, Richard and T. Ma Curdy (1999). "Labor supply: a review of alternative approaches", In Handbook of Labor Economics, vol.3A, edited by Orley Ashenfelter and David Card. Amsterdam: Elsevier.

Board of Trustees, Federal Old Age and Survivors Insurance and Disability insurance Trust Funds (2009). "The annual report of the board of Trustees of the Federal OASDI Trust Funds.

Boushey, Heather (2005). "Are women opting out? Debunking the myth", briefing paper (Washington, D.C., Center for Economic and Policy Research, November 2005).

Bradbury, K. and J.Katz (2005). "Women's rise: a work in progress", Regional Review, 14(3):58-67.

Cohany, Sharon R. and Emy Sok (2007). "Trends in labor force participation of married mothers with infants", Monthly Labor Review, February 2007, 9-16.

DiNatale, Marisa (2001). "Characteristics and preferences for alternative work arrangements, 1999", Monthly Labor Review, March 2001, 47-49.

DiNatale, Marisa and Stephanie Boraas (2002). "The labor force experience of women from 'Generation X'", Monthly Labor Review, March 2002, 3-15.

Golden, Lonnie (2001). "Flexible work schedules: what are we trading off to get them?" Monthly Labor Review, March 2001, 52-53.

Goldin, Claudia (1990). Understanding the gender gap, New York: Oxford University Press.

Greenhouse, Steven (2009). "Back to the grind: recession drives women who left the work force to return", New York Times, September 19, 2009.

Heim, Bradley T (2007). "The incredible shrinking elasticities: married female labor supply, 1978-2002", Journal of Human Resources, Fall 2007. 42(4):881.

Hirshman, Linda (2005). "Homeward Bound", American Prospect, November 21.

Hoffman, Saul D. (2009). "The changing impact of marriage and children on women's labor force participation", Monthly Labor Review, February 2009, 3-14. 
Hotchkiss, Julie L. (2006). "Changes in behavioral and characteristic determination of female labor force participation, 1975-2005", Economic Review, Federal Reserve Bank of Atlanta, Second Quarter, 2006, 1-20.

Jaeger, David A. (1997). "Reconciling educational attainment questions in the CPS and the Census", Monthly Labor Review, August, pp.36-40.

Juhn, Chinhui and K.M. Murphy (1997). "Wage inequality and family labor supply", Journal of Labor Economics, 15(1, pt.1):72-97.

Juhn, Chinhui and Simon Potter (2006). "Changes in labor force participation in the United States", Journal of Economic Perspectives, 20(3):27-46.

Mosisa, Abraham and Steven Hipple (2006). "Trends in labor force participation in the United States", Monthly Labor Review, October 2006, 35-57.

Olivetti, Claudia (2006). "Changes in women's hours of market work: the role of returns to experience", Review of Economic Dynamics, 9(4):557-587.

Polivka, Anne E. (1996). "Into Contingent and alternative employment: by choice?"

Story, Louise (2005). "Many Women at Elite Colleges Set Career Path to Motherhood", The New York Times, September 20, 2005.

Thornton, Arland and L.Young-DeMarco (2001). "Four decades of trends in attitudes toward family issues in the United States: the 1960s through the 1990s", Journal of Marriage and the Family, 63(4):1009-1037.

U.S. Department of Commerce, Bureau of the Census (2009). "Current Population Survey, March Supplement", as prepared by the Unicon Corporation in CPS Utilities.

Vere, James P. (2007). "'having it all' no longer: fertility, female labor supply, and the new life choices of Generation X", Demography, 44(4):821-828 (November).

Wallis, Claudia (2004). "The Case for Staying Home", Time, May 10, 2004.

Williams, Joan C. (2007). "The opt-out revolution revisited", American Prospect, February 19. 
Table 2: Instrumental Variables Labor Supply Estimates for Women by Marital Status Using Median Regression (Dependent Variable is Annual Hours, including Zeroes)

\begin{tabular}{|c|c|c|c|c|c|}
\hline & 1979-1981 & $\underline{1984-1986}$ & 1989-1991 & $\underline{1999-2001}$ & 2007-2009 \\
\hline \multicolumn{6}{|l|}{ Married Women: } \\
\hline Own logwage & $\begin{array}{c}705.3 \\
(18.42)\end{array}$ & $\begin{array}{c}821.5 \\
(16.69)\end{array}$ & $\begin{array}{c}736.7 \\
(13.33)\end{array}$ & $\begin{array}{c}371.0 \\
(15.91)\end{array}$ & $\begin{array}{c}380.3 \\
(13.28)\end{array}$ \\
\hline Husband's logwage & $\begin{array}{c}-441.1 \\
(16.33)\end{array}$ & $\begin{array}{c}-382.1 \\
(15.04)\end{array}$ & $\begin{array}{c}-339.0 \\
(12.57)\end{array}$ & $\begin{array}{c}-209.1 \\
(14.40)\end{array}$ & $\begin{array}{c}-224.5 \\
(11.97)\end{array}$ \\
\hline Other income ('000s) & $\begin{array}{l}-3.37 \\
(0.67)\end{array}$ & $\begin{array}{l}-3.73 \\
(0.57)\end{array}$ & $\begin{array}{l}-3.30 \\
(0.48)\end{array}$ & $\begin{array}{c}-1.11^{* *} \\
(0.51)\end{array}$ & $\begin{array}{l}-2.27 \\
(0.48)\end{array}$ \\
\hline Number of Children $<6$ & $\begin{array}{c}-484.9 \\
(10.70)\end{array}$ & $\begin{array}{c}-479.9 \\
(10.14)\end{array}$ & $\begin{array}{l}-492.2 \\
(8.42)\end{array}$ & $\begin{array}{c}-479.3 \\
(10.98)\end{array}$ & $\begin{array}{l}-421.8 \\
(8.92)\end{array}$ \\
\hline Number of Children 6-17 & $\begin{array}{l}-150.7 \\
(6.37)\end{array}$ & $\begin{array}{c}-163.6 \\
(4.17)\end{array}$ & $\begin{array}{l}-164.0 \\
(5.67)\end{array}$ & $\begin{array}{c}-162.7 \\
(6.88)\end{array}$ & $\begin{array}{c}-134.8 \\
(5.77)\end{array}$ \\
\hline \# of observations & 63,167 & 57.742 & 55,005 & 34.955 & 44,876 \\
\hline Own-wage elasticity & .736 & .760 & .596 & .271 & .281 \\
\hline Cross-wage elasticity & -.460 & -.354 & -.274 & -.153 & -.166 \\
\hline \multicolumn{6}{|l|}{ Standard errors in parentheses. } \\
\hline \multicolumn{6}{|c|}{$\begin{array}{l}\text { All coefficients are statistically significant at the } .01 \text { level or higher, except those indicated. } \\
* * \text { significant at the } .05 \text { level. }{ }^{*} \text { significant at the } .10 \text { level. }{ }^{N S} \text { not significant even at the } .10 \text { level. }\end{array}$} \\
\hline \multicolumn{6}{|c|}{$\begin{array}{l}\text { All regressions included age, age squared, four education dummies, and three race dummies for women (and for husbands } \\
\text { of married women). In addition, the regressions included two year dummies, eight region dummies, and indicators for } \\
\text { central city, other MSA and non-MSA. }\end{array}$} \\
\hline
\end{tabular}


Table 3: Hours Elasticities for Women by Subgroup

\begin{tabular}{|c|c|c|c|c|c|c|c|c|}
\hline & $\underline{\text { All }}$ & $\begin{array}{c}\text { More } \\
\text { than } 16 \\
\text { years of } \\
\text { education }\end{array}$ & $\begin{array}{l}16 \text { years of } \\
\text { education }\end{array}$ & $\begin{array}{l}\text { Less than } \\
16 \text { years of } \\
\text { education }\end{array}$ & $\underline{\text { Under } 35}$ & $\underline{35+}$ & $\begin{array}{l}\text { With No } \\
\text { Children } \\
\text { under } 18 \\
\end{array}$ & $\begin{array}{c}\text { With } \\
\text { Children }<6 \\
\end{array}$ \\
\hline \multicolumn{9}{|c|}{ Married women's own logwage: } \\
\hline 1979-1981 & .531 & .290 & .443 & .568 & .519 & .537 & .453 & .740 \\
\hline 1984-1986 & .591 & .269 & .463 & .657 & .647 & .550 & .473 & .864 \\
\hline 1989-1991 & .522 & .349 & .430 & .566 & .513 & .526 & .387 & .757 \\
\hline 1999-2001 & .253 & .079 & .221 & .289 & .191 & .272 & .223 & .326 \\
\hline 2007-2009 & .292 & .262 & .359 & .261 & .274 & .295 & .231 & .467 \\
\hline \multicolumn{9}{|c|}{ Single women's own logwage: } \\
\hline 1979-1981 & .324 & .123 & .151 & .384 & .299 & .348 & .241 & .593 \\
\hline 1984-1986 & .382 & $-.004^{\mathrm{NS}}$ & .105 & .504 & .315 & .443 & .293 & .688 \\
\hline 1989-1991 & .366 & .094 & .153 & .462 & .314 & .405 & .282 & .743 \\
\hline 1999-2001 & .115 & -.118 & .090 & .153 & .130 & .106 & .116 & .102 \\
\hline 2007-2009 & .202 & $.014^{\mathrm{NS}}$ & .125 & .263 & .106 & .258 & .216 & .117 \\
\hline \multicolumn{9}{|c|}{ Married women's cross-wage elasticity: } \\
\hline 1979-1981 & -.298 & .243 & -.343 & -.292 & -.274 & -.311 & -.187 & -.411 \\
\hline 1984-1986 & -.252 & .233 & -.240 & -.257 & -.226 & -.273 & -.170 & -.313 \\
\hline 1989-1991 & -.210 & .167 & -.216 & -.213 & -.190 & -.221 & -.135 & -.284 \\
\hline 1999-2001 & -.131 & .109 & -.179 & -.115 & -.113 & -.135 & -.049 & -.245 \\
\hline 2007-2009 & -.154 & .143 & -.188 & -.133 & -.143 & -.153 & -.089 & -.196 \\
\hline
\end{tabular}


Table 4: Married Women's Elasticities of Hours Worked with respect to Number of Children

\begin{tabular}{|c|c|c|c|c|c|c|c|}
\hline & $\underline{\text { All }}$ & $\begin{array}{l}\text { More than } \\
16 \text { years of } \\
\text { education }\end{array}$ & $\begin{array}{c}16 \text { years of } \\
\text { education }\end{array}$ & $\begin{array}{c}\text { Less than } 16 \\
\text { years of } \\
\text { education } \\
\end{array}$ & $\underline{\text { Under } 35}$ & $\underline{35+}$ & $\underline{\text { W/Children }<6}$ \\
\hline \multicolumn{8}{|c|}{ With respect to number of children $<6$ : } \\
\hline $1979-1981$ & -.167 & -.177 & -.230 & -.155 & -.326 & -.048 & -.492 \\
\hline 1984-1986 & -.145 & -.126 & -.200 & -.138 & -.280 & -.049 & -.428 \\
\hline 1989-1991 & -.127 & -.118 & -.172 & -.117 & -.245 & -.052 & -.371 \\
\hline $1999-2001$ & -.091 & -.078 & -.113 & -.084 & -.199 & -.049 & -.296 \\
\hline 2007-2009 & -.089 & -.098 & -.116 & -.077 & -.189 & -.049 & -.301 \\
\hline \multicolumn{8}{|c|}{ With respect to number of children aged 6-17: } \\
\hline $1979-1981$ & -.118 & -.084 & -.109 & -.124 & -.112 & -.123 & -.086 \\
\hline 1984-1986 & -.102 & -.080 & -.100 & -.108 & -.099 & -.108 & -.093 \\
\hline $1989-1991$ & -.088 & -.077 & -.091 & -.090 & -.080 & -.097 & -.082 \\
\hline $1999-2001$ & -.077 & -.069 & -.091 & -.079 & -.056 & -.087 & -.091 \\
\hline 2007-2009 & -.066 & -.072 & -.082 & -.060 & -.038 & -.075 & -.063 \\
\hline \multicolumn{8}{|c|}{ Coefficients used to calculate elasticities were all significant at more than a .01 level. } \\
\hline \multicolumn{8}{|c|}{ All elasticities calculated using weighted means, based on March Supplement Weights. } \\
\hline $\begin{array}{l}\text { Ill regressions included aq } \\
\text { ight region dummies, and }\end{array}$ & $\begin{array}{l}\text { redu } \\
\text { al cit }\end{array}$ & $\begin{array}{l}\text { nmies, and thre } \\
\text { r MSA. }\end{array}$ & ce dummies $\mathrm{f}$ & en and & In a & & rear \\
\hline
\end{tabular}


Table 5: Single Women's Elasticities of Hours Worked with respect to Number of Children

\begin{tabular}{|c|c|c|c|c|c|c|c|}
\hline & $\underline{\text { All }}$ & $\begin{array}{l}\text { More than } \\
16 \text { years of } \\
\text { education }\end{array}$ & $\begin{array}{c}16 \text { years of } \\
\text { education }\end{array}$ & $\begin{array}{c}\text { Less than } 16 \\
\text { years of } \\
\text { education }\end{array}$ & $\underline{\text { Under } 35}$ & $\underline{35+}$ & $\underline{\text { W/Children }<6}$ \\
\hline \multicolumn{8}{|c|}{ With respect to number of children $<6$ : } \\
\hline $1979-1981$ & -.034 & -.007 & -.014 & -.040 & -.055 & -.013 & -.328 \\
\hline 1984-1986 & -.035 & -.003 & -.016 & -.044 & -.058 & -.013 & -.295 \\
\hline 1989-1991 & -.033 & -.006 & -.011 & -.043 & -.058 & -.012 & -.297 \\
\hline $1999-2001$ & -.016 & -.005 & -.006 & -.021 & -.028 & -.009 & -.183 \\
\hline 2007-2009 & -.016 & -.006 & -.011 & -.020 & -.033 & -.007 & -.116 \\
\hline \multicolumn{8}{|c|}{ With respect to number of children aged 6-17: } \\
\hline $1979-1981$ & -.051 & -.010 & -.023 & -.060 & -.045 & -.054 & -.086 \\
\hline 1984-1986 & -.048 & -.020 & -.012 & -.058 & -.050 & -.045 & -.117 \\
\hline $1989-1991$ & -.032 & -.010 & -.017 & -.037 & -.044 & -.022 & -.057 \\
\hline $1999-2001$ & -.011 & -.006 & -.014 & -.009 & -.012 & -.011 & -.052 \\
\hline 2007-2009 & -.007 & -.017 & -.010 & -.005 & -.005 & -.009 & -.034 \\
\hline
\end{tabular}


Table 6: Predicted Changes in Unconditional Annual Work Hours for Married and Single Women in the 1980-1990 period (using the 1989-1991 estimated equations)

\begin{tabular}{|c|c|c|c|c|c|c|c|c|}
\hline & All Women & $\begin{array}{l}>16 \text { Years } \\
\text { Education }\end{array}$ & $\begin{array}{c}16 \text { years } \\
\text { Education }\end{array}$ & $\begin{array}{l}<16 \text { Years } \\
\text { Education }\end{array}$ & Under 35 & $35+$ & $\begin{array}{l}\text { No Children } \\
<18\end{array}$ & $\begin{array}{c}\text { With } \\
\text { Children }<6\end{array}$ \\
\hline \multicolumn{9}{|l|}{ Married Women: } \\
\hline 1. Own logwage & 59.77 & 87.92 & 104.24 & 24.27 & 28.11 & 82.86 & 56.20 & 61.50 \\
\hline 2. Husband's logwage & 10.16 & -15.15 & -3.03 & 18.87 & 16.69 & 6.64 & 2.58 & 10.34 \\
\hline 3. Other income & -1.44 & -6.47 & -2.15 & -0.40 & -0.90 & -1.65 & $-0.92^{\mathrm{NS}}$ & $-0.68^{\mathrm{NS}}$ \\
\hline 4. Age & 0.99 & $-5.44^{\mathrm{NS}}$ & $-12.01^{\mathrm{NS}}$ & 4.12 & $-2.34^{\mathrm{NS}}$ & 10.19 & 5.77 & $-0.74^{\mathrm{NS}}$ \\
\hline 5. Husband's age & $-0.29^{\mathrm{NS}}$ & $7.62^{\mathrm{NS}}$ & $1.75^{\mathrm{NS}}$ & $-0.39^{\mathrm{NS}}$ & $-0.56^{\mathrm{NS}}$ & $-0.72^{\mathrm{NS}}$ & $0.18^{\mathrm{NS}}$ & $0.49^{\mathrm{NS}}$ \\
\hline 6. Education & 19.49 & & & 16.96 & 8.33 & 28.55 & 26.43 & 5.48 \\
\hline 7. Husband's education & 0.41 & $0.18^{\mathrm{NS}}$ & 6.60 & 3.33 & 2.96 & 2.28 & 4.19 & -1.16 \\
\hline 8. Number of children & 16.99 & 4.65 & 23.68 & 16.79 & 4.72 & 15.77 & & 8.05 \\
\hline 9. Race & $0.96^{\mathrm{NS}}$ & $-0.82^{\mathrm{NS}}$ & $-2.82^{\mathrm{NS}}$ & 1.99 & -0.52 & 2.36 & -0.60 & 0.26 \\
\hline 10. Husband's race & 0.39 & $0.01^{\mathrm{NS}}$ & 3.24 & $-0.19^{\mathrm{NS}}$ & -1.12 & 1.37 & -1.42 & 0.57 \\
\hline 11. Region/MSA & -0.36 & 3.07 & -6.62 & 1.25 & 0.19 & -1.20 & -2.10 & -4.52 \\
\hline 12. Total actual hours $\Delta$ & 276.42 & 180.93 & 292.7 & 261.70 & 246.42 & 294.67 & 234.01 & 287.15 \\
\hline 13. Total explained hrs $\Delta$ & 107.06 & 75.58 & 112.86 & 86.6 & 55.56 & 146.46 & 90.33 & 79.58 \\
\hline $\begin{array}{l}\text { 14.Total unexplained } \Delta \\
\text { Single Women: }\end{array}$ & 169.36 & 105.35 & 179.84 & 175.1 & 190.86 & 148.21 & 143.68 & 207.57 \\
\hline 15. Own logwage & 19.45 & 23.90 & 33.51 & -8.14 & -11.34 & 53.98 & 32.24 & -32.04 \\
\hline 16. Other income & -1.03 & $-0.09^{\mathrm{NS}}$ & -1.09 & -0.62 & -1.26 & -0.67 & -1.15 & -0.95 \\
\hline 17. Age & 4.24 & 22.95 & 3.30 & 4.90 & $2.40^{\mathrm{NS}}$ & $7.28^{\mathrm{NS}}$ & 2.66 & $-0.50^{\mathrm{NS}}$ \\
\hline 18. Education & 36.42 & & & 32.90 & 15.58 & 49.97 & 39.41 & 20.19 \\
\hline 19. Number of children & 10.30 & 0.48 & 10.37 & 6.43 & 2.80 & 12.13 & & 9.89 \\
\hline 20. Race & -1.20 & -4.53 & -3.74 & -1.01 & -2.93 & -0.26 & -0.80 & 3.38 \\
\hline 21. Region/MSA & 8.91 & 0.65 & -0.22 & 12.34 & 3.01 & 14.74 & 6.73 & 4.86 \\
\hline 22. Total actual hours $\Delta$ & 118.2 & 86.50 & 160.68 & 87.54 & 57.19 & 173.11 & 116.78 & 72.43 \\
\hline 23. Total explained hours $\Delta$ & 77.08 & 43.10 & 42.13 & 46.82 & 8.27 & 137.17 & 79.09 & 31.89 \\
\hline 24. Total unexplained $\Delta$ & 41.12 & 43.40 & 118.55 & 40.72 & 48.92 & 35.94 & 37.69 & 40.54 \\
\hline
\end{tabular}


Table 7: Predicted Changes in Unconditional Annual Work Hours for Married and Single Women in the 2000-2008 period (using the 2007-2009 estimated equations)

\begin{tabular}{|c|c|c|c|c|c|c|c|c|}
\hline & All women & $\begin{array}{l}>16 \text { Years } \\
\text { Education }\end{array}$ & $\begin{array}{l}16 \text { years } \\
\text { Education }\end{array}$ & $\begin{array}{l}<16 \text { Years } \\
\text { Education }\end{array}$ & Under 35 & $35+$ & $\begin{array}{l}\text { No Children } \\
<18\end{array}$ & $\begin{array}{c}\text { With } \\
\text { Children }<6\end{array}$ \\
\hline \multicolumn{9}{|l|}{ Married Women: } \\
\hline 1. Own logwage & 21.06 & -3.16 & 2.03 & 5.69 & 21.01 & 20.60 & 10.01 & 36.31 \\
\hline 2. Husband's logwage & -2.10 & -0.04 & -3.96 & 5.37 & -3.93 & -1.18 & 4.04 & -9.17 \\
\hline 3. Other income & 0.64 & $-1.34^{\mathrm{NS}}$ & 2.37 & $0.35^{\mathrm{NS}}$ & $-0.51^{\mathrm{NS}}$ & 0.80 & 1.12 & $-0.13^{\mathrm{NS}}$ \\
\hline 4. Age & -4.24 & 7.29 & $-1.32^{\mathrm{NS}}$ & -6.59 & $-1.79^{\mathrm{NS}}$ & $-5.11^{\mathrm{NS}}$ & -4.60 & 1.52 \\
\hline 5. Husband's age & 1.04 & $-10.65^{\mathrm{NS}}$ & $-0.24^{\mathrm{NS}}$ & 1.22 & $0.58^{\mathrm{NS}}$ & $1.37^{\mathrm{NS}}$ & 1.97 & $-1.96^{\mathrm{NS}}$ \\
\hline 6. Education & 13.76 & & & -.72 & 18.74 & 11.39 & 10.51 & 14.64 \\
\hline 7. Husband's education & -4.49 & 0.60 & 0.88 & -0.14 & -8.26 & -3.00 & -0.77 & -14.70 \\
\hline 8. Number of children & -6.80 & -30.32 & -11.66 & -1.17 & 3.62 & -3.07 & & -1.98 \\
\hline 9. Race & $0.59^{\mathrm{NS}}$ & $3.48^{\mathrm{NS}}$ & $2.80^{\mathrm{NS}}$ & $-1.89^{\mathrm{NS}}$ & $-2.84^{\mathrm{NS}}$ & 2.31 & $0.04^{\mathrm{NS}}$ & 3.41 \\
\hline 10. Husband's race & -3.87 & -13.00 & -6.27 & $-1.30^{\mathrm{ns}}$ & -14.19 & 0.46 & -8.58 & -7.00 \\
\hline 11. Region/MSA & -6.79 & $0.72^{\mathrm{NS}}$ & -11.37 & -6.80 & -9.28 & -6.58 & -1.67 & -10.43 \\
\hline 12. Total actual hours $\Delta$ & -13.46 & -28.66 & -51.88 & -26.11 & -6.19 & -16.42 & -37.24 & -14.98 \\
\hline 13. Total explained hrs $\Delta$ & 8.79 & -46.42 & -26.74 & -5.99 & 3.24 & 10.02 & 12.06 & 10.56 \\
\hline $\begin{array}{l}\text { 14.Total unexplained } \Delta \\
\text { Single Women: }\end{array}$ & -22.25 & 17.76 & -25.14 & -20.12 & -9.43 & -26.44 & -49.30 & -25.54 \\
\hline 15. Own logwage & -3.03 & $-0.42^{\mathrm{NS}}$ & -2.63 & -9.38 & 0.22 & -6.46 & -6.03 & -1.57 \\
\hline 16. Other income & 0.64 & $1.57^{\mathrm{NS}}$ & $2.70^{\mathrm{NS}}$ & $-0.24^{\mathrm{NS}}$ & $0.59^{\mathrm{NS}}$ & $0.67^{\mathrm{NS}}$ & $1.36^{\mathrm{NS}}$ & $-0.12^{\mathrm{NS}}$ \\
\hline 17. Age & -5.61 & -11.63 & -7.14 & -5.57 & $-3.77^{\mathrm{NS}}$ & -6.73 & -4.82 & -4.04 \\
\hline 18. Education & 13.54 & & & 9.93 & 17.52 & 11.33 & 13.91 & 7.49 \\
\hline 19. Number of children & -3.21 & -8.30 & -6.77 & -3.83 & -6.04 & -1.63 & & -2.47 \\
\hline 20. Race & 0.94 & $-7.89^{\mathrm{NS}}$ & -5.17 & 3.83 & -0.69 & 2.53 & -1.12 & 4.64 \\
\hline 21. Region/MSA & 3.15 & 2.82 & 1.23 & 4.32 & 2.57 & 3.37 & 2.52 & 7.17 \\
\hline 22. Total actual hours $\Delta$ & -101.48 & -99.56 & -73.4 & -122.15 & -104.98 & -99.21 & -105.96 & -84.28 \\
\hline 23. Total explained hours $\Delta$ & 6.44 & -23.86 & -17.78 & -0.93 & 10.41 & 3.07 & 5.81 & 11.11 \\
\hline 24. Total unexplained $\Delta$ & -107.92 & -75.70 & -55.62 & & -115.39 & -102.28 & -111.77 & -95.39 \\
\hline
\end{tabular}


Table 9: Characteristics of women who dropped out of the labor force ${ }^{6}$, relative to those who remained

\begin{tabular}{|c|c|c|c|c|c|}
\hline & Hours worked & Hourly wage & $\begin{array}{c}\text { Other } \\
\text { income }^{7}\end{array}$ & $\begin{array}{c}\text { Number of } \\
\text { Children }<6\end{array}$ & $\begin{array}{c}\text { Number of } \\
\text { Children } \\
\text { 6-17 }\end{array}$ \\
\hline \multicolumn{6}{|l|}{ All Single Women } \\
\hline \multicolumn{6}{|c|}{ Less than 16 yrs education: } \\
\hline Prior to 1999 & .49 & .60 & .89 & 2.86 & 1.53 \\
\hline $1999-2001$ & .52 & .95 & .77 & 2.00 & 1.27 \\
\hline 2007-2009 & .54 & .85 & .66 & 2.16 & 1.23 \\
\hline \multicolumn{6}{|l|}{16 yrs education: } \\
\hline Prior to 1999 & .57 & .83 & 1.54 & 2.53 & 1.23 \\
\hline 1999-2001 & .52 & 1.03 & .95 & 1.56 & .79 \\
\hline 2007-2009 & .51 & .94 & 1.40 & 1.95 & .84 \\
\hline \multicolumn{6}{|c|}{ More than 16 yrs education: } \\
\hline Prior to 1999 & .42 & .80 & 1.73 & .92 & .95 \\
\hline $1999-2001$ & .55 & 1.14 & 1.90 & 1.23 & .24 \\
\hline 2007-2009 & .59 & .96 & .39 & .56 & .78 \\
\hline \multicolumn{6}{|l|}{ All Childless Women } \\
\hline \multicolumn{6}{|c|}{ Less than 16 yrs education: } \\
\hline Prior to 1999 & .47 & .88 & 1.27 & & \\
\hline $1999-2001$ & .53 & .94 & .98 & & \\
\hline 2007-2009 & .55 & .90 & .90 & & \\
\hline \multicolumn{6}{|l|}{16 yrs education: } \\
\hline Prior to 1999 & .53 & .86 & 2.21 & & \\
\hline 1999-2001 & .51 & 1.06 & 1.35 & & \\
\hline 2007-2009 & .54 & .92 & 1.14 & & \\
\hline \multicolumn{6}{|c|}{ More than 16 yrs education: } \\
\hline Prior to 1999 & .50 & .84 & 1.70 & & \\
\hline $1999-2001$ & .55 & 1.09 & 1.26 & & \\
\hline 2007-2009 & .56 & 1.09 & .76 & & \\
\hline
\end{tabular}

\footnotetext{
${ }^{6} \mathrm{~A}$ woman is defined as having dropped out of the labor force if she worked positive hours in year $\mathrm{t}-1$, and was not in the labor force in year $t$.

${ }^{7}$ Interest, dividends and rent
} 
Figure 1: Labor force participation of women aged 25-54 by marital status ${ }^{8}$, education and presence of children.
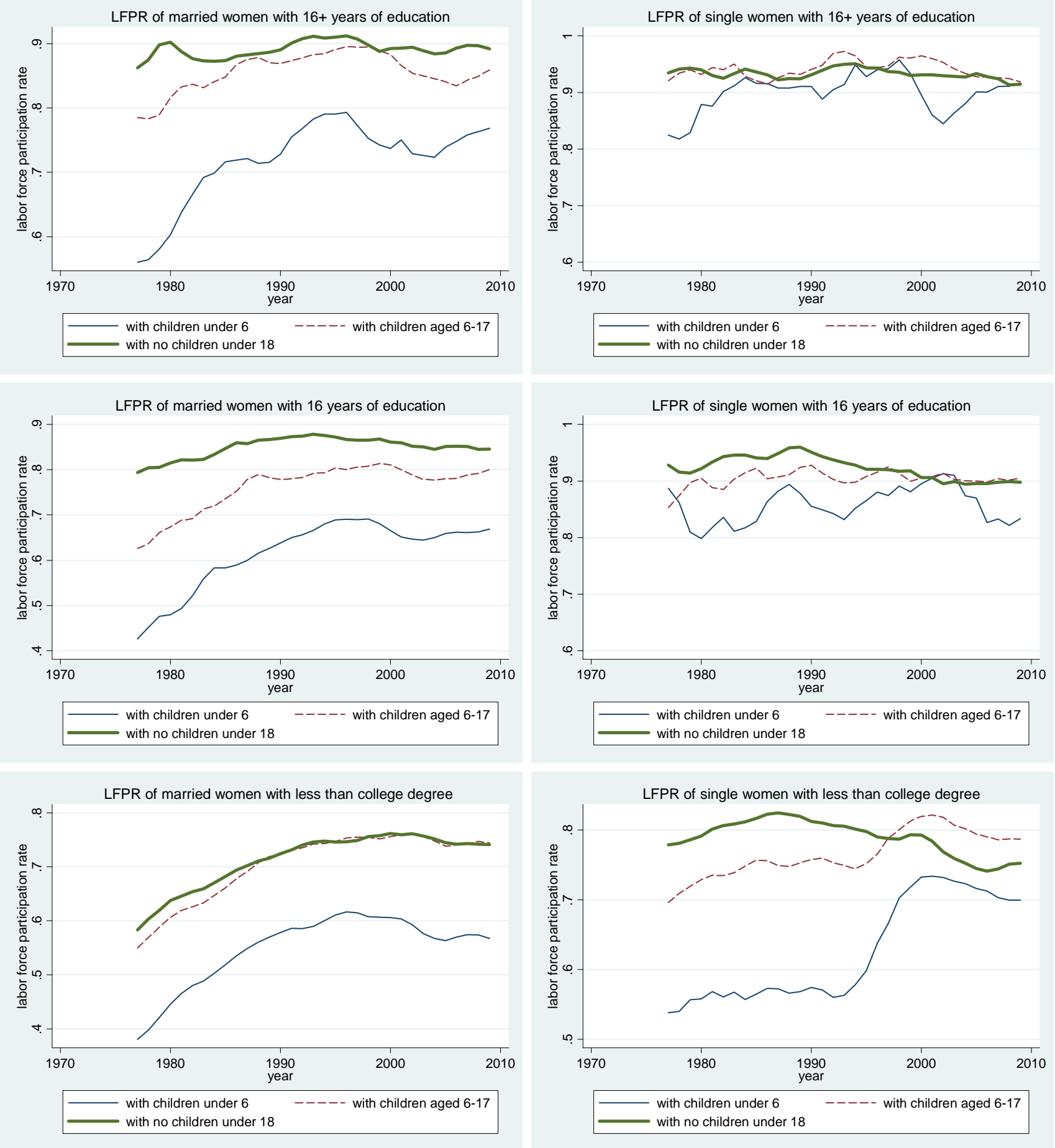

8 "Single" here includes married women with spouse absent, and divorced, separated, widowed and never-married women. "With children 6-17" refers to women with only children 6-17 - that is, no children under 6. 
Figure 2: Labor force participation of women with children under 6, by age, marital status ${ }^{9}$ and education
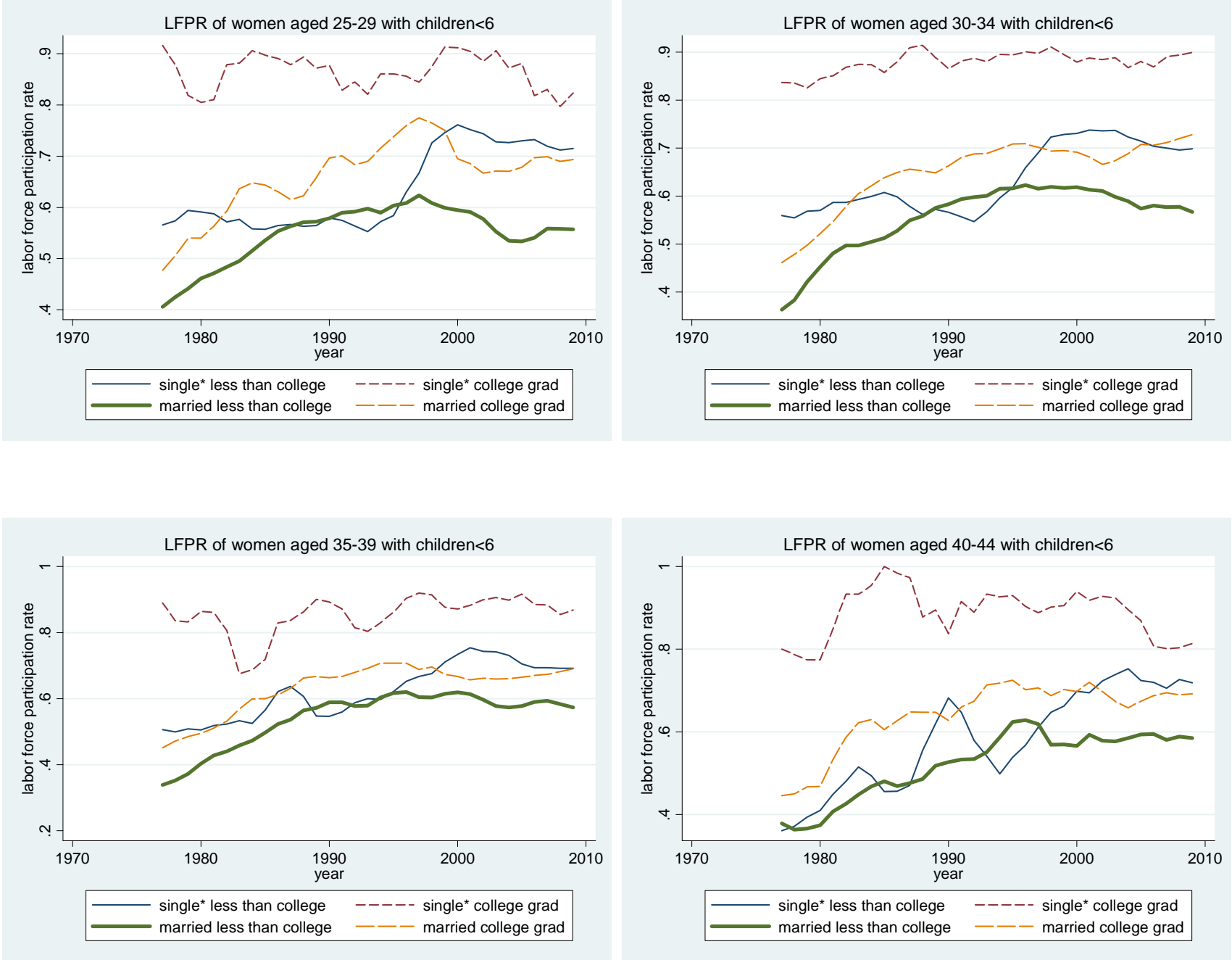

9 "Single" here includes married women with spouse absent, and divorced, separated, widowed and never-married women. "Less than college" refers to those with less than 16 years of education. "College grad" refers to those with 16+ years of education. 
Figure 3: Labor force participation of women with no children under 18, by age, marital status ${ }^{10}$ and education
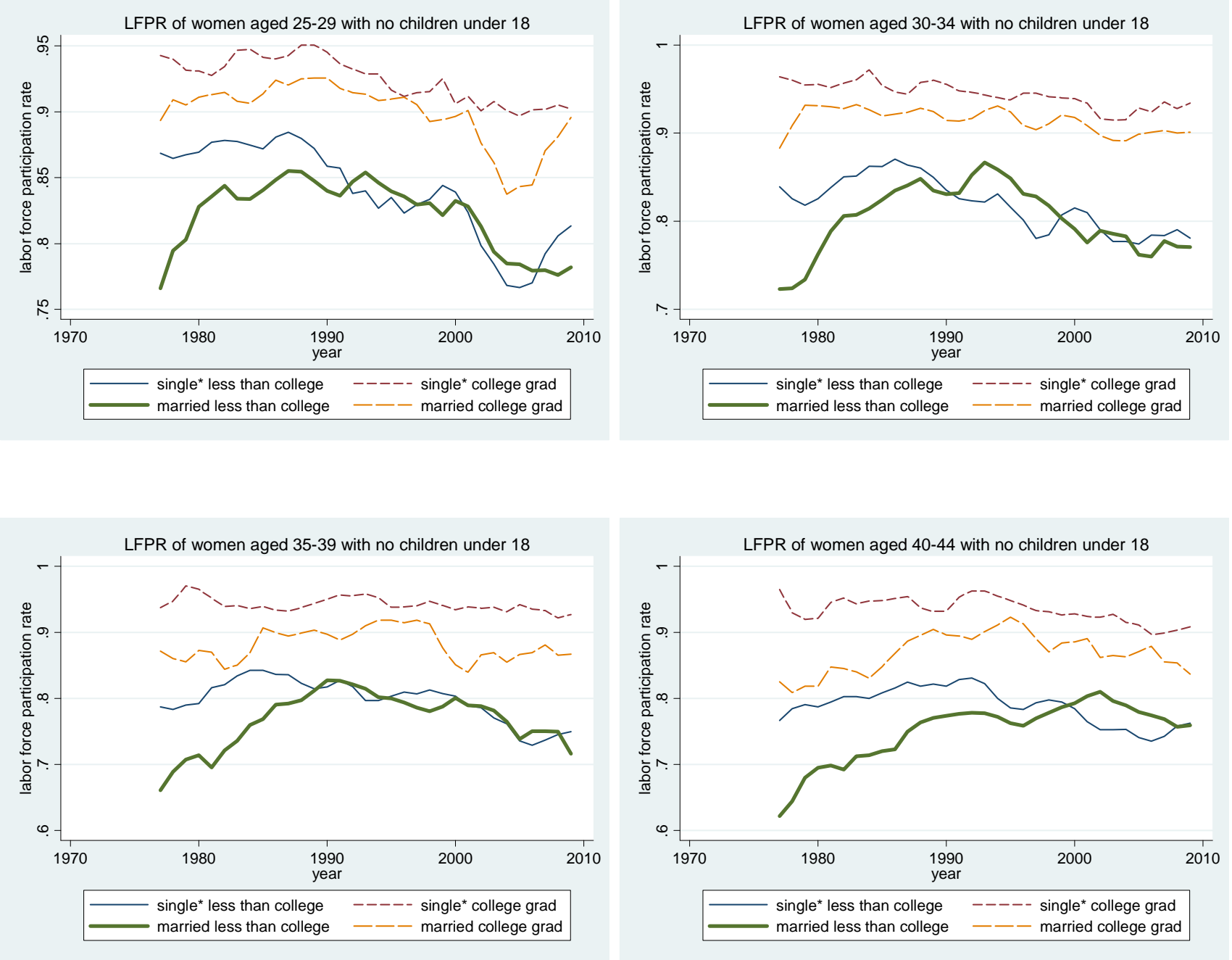

10 "Single" here includes women with spouse absent, and divorced, separated, widowed and never-married women. "Less than college" refers to those with less than 16 years of education, and "college grad" refers to those with 16+ years of education. 
Figure 4: Average observed wages ${ }^{11}$ of women aged 25-54, in 2008 dollars
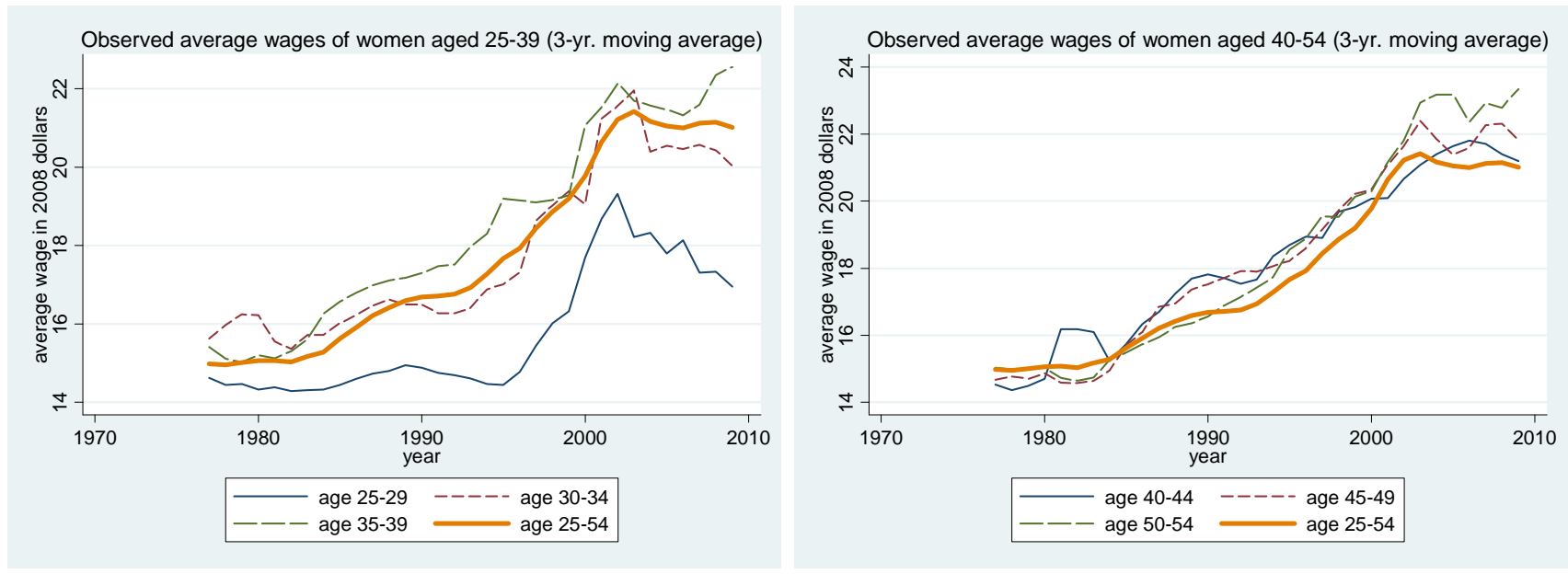

${ }^{11}$ These are the observed wages of women who worked positive hours and reported a wage, rather than imputed or instrumented wages. 


\section{$\underline{\text { Data Appendix }}$}

The data used in these analyses were taken from the annual March Current Population Survey (CPS) as compiled by Unicon Corporation in "CPS Utilities".

For the graphs of labor force participation rates and average wages, the years 1976-2009 were used. These data are for all women aged 25-54, weighted using the March Supplement Weights. Labor force participation was identified using the CPS employment status recode. Annual wages were calculated as income from wages and salary divided by annual hours, which in turn was calculated as weeks worked in the year times usual hours worked per week.

For the econometric analyses, the years 1979-1981, 1984-1986, 1989-1991, 1999-2001, and 2007-2009 were used in order to attempt to reproduce and update results in Blau and Kahn (2007), with 1984-1986 added as a check on the pattern of changes in the 1980s. Data cover women aged 25-54 only, and include married men with spouse present also aged 25-54. Single women in the analyses include married women with spouse absent, and divorced, separated, widowed, and never-married women. Husbands and wives were matched using the hierarchical structure of the CPS data files, since it was determined that not all records are unique for matching based on the available family variables ${ }^{12}$.

As in Blau and Kahn, those with allocated hours or weeks worked were dropped from the data. In addition, persons in the military have been excluded and, because Blau and Khan selected this age group in order "to abstract from issues of school and retirement for both husbands and wives", those who are retired were specifically excluded as well. An attempt was made to exclude those enrolled in school, but it was determined that the data are not consistent over the years covered. The numbers dropped in each category are indicated in Table A-1.

The March Supplement Weights were used in all analyses, and in order to ensure that each year was given equal weight in each trio of years, the weights were divided by the sum of weights in each year to make them sum to one in each year. Because the method of reporting educational attainment was changed beginning in 1993, Jaeger's (1997) correspondence method was used to determine the highest grade completed after that date.

All dollar figures are expressed in constant 2008 dollars. As in Blau and Kahn (2007), top-coded wages were multiplied by a factor of 1.45 . Income other than wages and salary was calculated as the sum of income from interest, dividends, and rent. Following Blau and Kahn, wages were imputed for those who were self-employed, those who reported no income, and those whose hourly wage was calculated as falling outside the range of \$2.50 $\$ 250$ in 2008 dollars. The imputation process was based on regressions of reported valid wages. For those reporting less than 20 weeks worked, imputed wages were based on a regression using those with a valid wage who worked less than 20 weeks. For those reporting 20 or more weeks worked, imputed wages were based on a regression using those with a valid wage who reported 20 or more weeks worked. This process was carried out separately for married women with spouse present, single women, and husbands with a spouse present. The regressors used were age, age squared, five education categories (less than 12 years, 12 years,13-15 years, 16 years, and 17+ years), four race categories (white, black, Hispanic and other), eight region dummies and metropolitan area indicators (central city, other MSA and non-MSA).

\footnotetext{
${ }^{12}$ This was confirmed by Greg Weyland at the Census Bureau, and Eanswythe Grabowski at Unicon, in communications dated September 22, 2009.
} 
Table A-1: Tabulation of numbers of observations excluded from analysis

\begin{tabular}{|c|c|c|c|c|c|}
\hline & $1979-1981$ & 1984-1986 & 1989-1991 & 1999-2001 & 2007-2009 \\
\hline \multicolumn{6}{|l|}{ Married women } \\
\hline Military & 1 & 0 & 0 & 0 & 0 \\
\hline Retired & 16 & 28 & 26 & 60 & 32 \\
\hline \multicolumn{6}{|l|}{ Single women } \\
\hline Military & 6 & 0 & 0 & 0 & 0 \\
\hline Retired & 9 & 24 & 20 & 33 & 37 \\
\hline \multicolumn{6}{|l|}{ Married men } \\
\hline Military & 66 & 0 & 0 & 0 & 0 \\
\hline Retired & 171 & 199 & 218 & 131 & 101 \\
\hline \multicolumn{6}{|c|}{ Observations remaining after exclusions } \\
\hline Married women & 63,167 & 57,742 & 55,005 & 34,955 & 44,876 \\
\hline Single women & 26,821 & 30,222 & 32,537 & 30,770 & 47,945 \\
\hline
\end{tabular}


Table A-2: Mean Values of Selected Variables in the Sample for Married Women Aged 25-54

\begin{tabular}{|lcccccc|}
\hline & $\underline{\mathbf{1 9 7 9 - 1 9 8 1}}$ & $\underline{\mathbf{1 9 8 4 - 1 9 8 6}}$ & $\underline{\mathbf{1 9 8 9 - 1 9 9 1}}$ & $\underline{\mathbf{1 9 9 9 - 2 0 0 1}}$ & $\underline{\mathbf{2 0 0 7 - 2 0 0 9}}$ \\
Annual hours worked & 958.781 & 1080.358 & 1235.199 & 1368.038 & 1354.574 \\
(including zeroes) & & & & & & \\
Own log imputed wage & 2.494 & 2.524 & 2.587 & 2.726 & 2.779 \\
Own log valid wage & 2.553 & 2.597 & 2.654 & 2.773 & 2.843 \\
Spouse log imputed wage & $(36,912$ obs) & $(35,991$ obs) & $(36,781$ obs) & $(24,500$ obs) & $(31,262$ obs) \\
Spouse log valid wage & 3.135 & 3.099 & 3.096 & 3.142 & 3.152 \\
Nonwage income ('000s) & 3.150 & 3.118 & 3.113 & 3.156 & 3.175 \\
Age & 2.082 & 2.609 & 2.864 & 3.767 & 3.004 \\
Less than grade 12 & 37.0 & 36.9 & 37.3 & 39.2 & 39.5 \\
Grade 12 & .191 & .145 & .121 & .097 & .081 \\
13-15 years of education & .473 & .462 & .437 & .332 & .273 \\
16 years of education & .173 & .200 & .213 & .286 & .278 \\
16+ years of education & .108 & .124 & .148 & .200 & .248 \\
Spouse less than grade 12 & .055 & .071 & .080 & .085 & .120 \\
Spouse grade 12 & .212 & .164 & .135 & .104 & .088 \\
Spouse some college & .363 & .368 & .367 & .307 & .287 \\
Spouse college graduate & .175 & .192 & .206 & .252 & .267 \\
Number of children $<6$ & .249 & .276 & .291 & .317 & .359 \\
Number of children 6-17 & .420 & .449 & .449 & .388 & .418 \\
Number of observations & 63,167 & 57,742 & 55,005 & 34,955 & 44,876 \\
\hline
\end{tabular}


Table A-3: Mean Values of Selected Variables in the Sample for Single Women Aged 25-54

\begin{tabular}{|lcccccc|}
\hline & $\mathbf{1 9 7 9 - 1 9 8 1}$ & $\underline{\mathbf{1 9 8 4 - 1 9 8 6}}$ & $\underline{\mathbf{1 9 8 9 - 1 9 9 1}}$ & $\underline{\mathbf{1 9 9 9 - 2 0 0 1}}$ & $\underline{\mathbf{2 0 0 7 - 2 0 0 9}}$ \\
$\begin{array}{l}\text { Annual hours worked } \\
\text { (including zeroes) }\end{array}$ & 1401.042 & 1440.73 & 1519.24 & 1615.781 & 1514.305 \\
Own log imputed wage & 2.534 & 2.547 & 2.569 & 2.668 & 2.658 \\
Own log valid wage & 2.601 & 2.626 & 2.657 & 2.626 & 2.706 \\
Nonwage income ('000s) & $(19,973$ obs) & $(22,326$ obs $)$ & $(24,221$ obs) & $(23,750$ obs) & $(35,582$ obs) \\
Age & 1.371 & 1.726 & 1.662 & 1.871 & 1.157 \\
Less than grade 12 & 36.88 & 36.30 & 36.69 & 38.37 & 38.69 \\
Grade 12 & .260 & .199 & .178 & .121 & .105 \\
$13-15$ years of education & .386 & .395 & .387 & .320 & .304 \\
16 years of education & .175 & .196 & .211 & .301 & .311 \\
$16+$ years of education & .078 & .125 & .134 & .184 & .197 \\
Number of children $<6$ & .164 & .175 & .189 & .148 & .171 \\
Number of children 6-17 & .714 & .590 & .529 & .506 & .501 \\
Number of observations & 26,821 & 30,222 & 32,537 & 30,770 & 47,945 \\
\hline
\end{tabular}

